Wittgenstein and Meaning in Life 
This page intentionally left blank 


\section{Wittgenstein and Meaning in Life}

In Search of the Human Voice

Reza Hosseini

Rhodes University, South Africa 
(C) Reza Hosseini 2015

Softcover reprint of the hardcover 1st edition 2015 978-1-137-44090-7

All rights reserved. No reproduction, copy or transmission of this publication may be made without written permission.

No portion of this publication may be reproduced, copied or transmitted save with written permission or in accordance with the provisions of the Copyright, Designs and Patents Act 1988, or under the terms of any licence permitting limited copying issued by the Copyright Licensing Agency, Saffron House, 6-10 Kirby Street, London EC1N 8TS.

Any person who does any unauthorized act in relation to this publication may be liable to criminal prosecution and civil claims for damages.

The author has asserted his right to be identified as the author of this work in accordance with the Copyright, Designs and Patents Act 1988.

First published 2015 by

PALGRAVE MACMILLAN

Palgrave Macmillan in the UK is an imprint of Macmillan Publishers Limited, registered in England, company number 785998, of Houndmills, Basingstoke, Hampshire RG216XS.

Palgrave Macmillan in the US is a division of St Martin's Press LLC, 175 Fifth Avenue, New York, NY 10010.

Palgrave Macmillan is the global academic imprint of the above companies and has companies and representatives throughout the world.

Palgrave ${ }^{\circledR}$ and Macmillan ${ }^{\circledR}$ are registered trademarks in the United States, the United Kingdom, Europe and other countries.

ISBN 978-1-349-49464-4 DOI 10.1057/9781137440914

ISBN 978-1-137-44091-4 (eBook)

This book is printed on paper suitable for recycling and made from fully managed and sustained forest sources. Logging, pulping and manufacturing processes are expected to conform to the environmental regulations of the country of origin.

A catalogue record for this book is available from the British Library.

A catalog record for this book is available from the Library of Congress. 
To my father 
Don't look for anything behind the phenomena; they themselves are the theory.

Johann Wolfgang von Goethe 


\section{Contents}

Acknowledgements

viii

$\begin{array}{ll}\text { Introduction } & 1\end{array}$

1 Book of Facts, Book of Values 13

2 The Limits of Justification 24

3 Aspect-Seeing and Meaning in Life 47

4 In Defence of the Ordinary 67

5 On Detachment or Why the Shopkeeper Does Not Investigate His Apples $\quad 84$

6 The Human Voice: The Confessional Nature of Enquiring into Life's Meaning 117

$\begin{array}{ll}\text { Coda } & 147\end{array}$

$\begin{array}{ll}\text { Notes } & 152\end{array}$

$\begin{array}{ll}\text { Bibliography } & 163\end{array}$

$\begin{array}{ll}\text { Index } & 175\end{array}$ 


\section{Acknowledgements}

An idea expands like a seed in the soil. So many things have to happen for it to grow. There are people involved here; places are involved here too, like the streets of Tehran.

I am grateful to many people whose comments, suggestions or company over the years have influenced the development of my thoughts in this work: Johan Snyman, Thaddeus Metz, John Cottingham, Alex Broadbent, Ward E. Jones, Samantha Vice, Hans Sluga, David Kishik, Raphael Winkler, Oisín Eoin Keohane, Tyler Burge, Neil Van Leeuwen, Kianoush Eslami, Ehsan Bateni, Jan Koster, Leon Marincowitz and Arianne Conty.

I received valuable comments on the entire manuscript from James C. Klagge and David E. Cooper, which were crucial in the development of some of the ideas in this book. I'm indebted to their generosity. It goes without saying that none is to blame for the results.

I am grateful to the Philosophy Department at the University of Johannesburg for providing financial support to present a chapter of this work at the 35th International Ludwig Wittgenstein Symposium in 2012. I am thankful to the Allan Gray Centre for Leadership Ethics (AGCLE) at Rhodes University for giving me the support to work on the manuscript. I am especially thankful to Julie Borland, Lindsay Kelland and Pedro Tabensky for their friendship and collegiality.

An earlier version of Chapter 6 was presented at a research workshop organised by the University of Adelaide in 2014. The feedback I received from the participants of this workshop was reassuring, and the hospitality of Andrew Gleeson made my trip a memorable one. I'm grateful to Andrew, and I thank Christopher Cordner and Craig Taylor.

An earlier version of Chapter 3 was presented at the 37 th International Ludwig Wittgenstein Symposium in Austria, and I'm grateful to the participants, especially Alois Pichler, for their useful comments and suggestions.

I should also thank Brendan George, senior commissioning editor at Palgrave Macmillan, for his confidence in the project, Ryan Dunlop, the copy editor of the book and the entire team at Newgen Knowledge Works for their prompt typesetting and proofreading, and the anonymous readers for their constructive comments and suggestions. 
In 2008, I left my home country, Iran, in search of something I couldn't tell what it was by then, something I was conscious of but could not apprehend, and I landed in South Africa out of all the places. But now I can tell what it was and for which I am deeply grateful to my wife, Lebo Makubetse, who made me feel at home by virtue of which I came to realise why I had begun my journey in the first place. Kea go bona, wa mpona! 
'On the 28th of August, 1749, at mid-day, as the clock struck twelve, I came into the world'.

Goethe, Poetry and Truth: From My Own Life

'When I was fifteen years old or sixteen I carried around in the streets of Brooklyn a paperback copy of Plato's Republic, front cover facing outward. I had read only some of it and understood less. . . How much I wanted an older person to notice me carrying it and be impressed, to pat me on the shoulder and say ... I didn't know what exactly. I sometimes wonder, not without uneasiness, what that young man of fifteen or sixteen would think of what he has grown up to do'.

Robert Nozick, The Examined Life

'Midway upon the journey of our life

I found myself within a forest dark,

For the straightforward pathway had been lost'.

Dante Alighieri, Divine Comedy

'Tell them I've had a wonderful life'.

Ludwig Wittgenstein 